\title{
NONLINEAR MODELS FOR DESCRIPTION OF CACAO FRUIT GROWTH WITH ASSUMPTION VIOLATIONS ${ }^{1}$
}

\author{
JOEL AUGUSTO MUNIZ* ${ }^{*}$, MICHERLANIA DA SILVA NASCIMENTO² ${ }^{2}$ TALES JESUS FERNANDES ${ }^{2}$
}

\begin{abstract}
Cacao (Theobroma cacao L.) is an important fruit in the Brazilian economy, which is mainly cultivated in the southern State of Bahia. The optimal stage for harvesting is a major factor for fruit quality and the knowledge on its growth curves can help, especially in identifying the ideal maturation stage for harvesting. Nonlinear regression models have been widely used for description of growth curves. However, several studies in this subject do not consider the residual analysis, the existence of a possible dependence between longitudinal observations, or the sample variance heterogeneity, compromising the modeling quality. The objective of this work was to compare the fit of nonlinear regression models, considering residual analysis and assumption violations, in the description of the cacao (clone Sial-105) fruit growth. The data evaluated were extracted from Brito and Silva (1983), who conducted the experiment in the Cacao Research Center, Ilheus, State of Bahia. The variables fruit length, diameter and volume as a function of fruit age were studied. The use of weighting and incorporation of residual dependencies was efficient, since the modeling became more consistent, improving the model fit. Considering the first-order autoregressive structure, when needed, leads to significant reduction in the residual standard deviation, making the estimates more reliable. The Logistic model was the most efficient for the description of the cacao fruit growth.
\end{abstract}

Keywords: Biological interpretation. Biometric measurement. Logistic model. Theobroma cacao L..

\section{MODELOS NÃO LINEARES NA DESCRIÇÃO DO CRESCIMENTO DE FRUTOS DE CACAU COM VIOLAÇÕES DOS PRESSUPOSTOS}

RESUMO - O cacau é um importante produto para a economia brasileira, sendo cultivado principalmente no sul da Bahia. O ponto ótimo de colheita é um dos principais fatores de perda na qualidade do fruto e o conhecimento de suas curvas de crescimento pode auxiliar principalmente na identificação deste ponto. Os modelos de regressão não linear tem sido amplamente utilizados na descrição de curvas de crescimento. No entanto, em várias pesquisas nesse sentido não é realizada a análise de resíduos, não consideram a existência de uma possível dependência entre as observações longitudinais e nem a heterogeneidade de variâncias amostrais, comprometendo a qualidade da modelagem. Assim, este trabalho objetivou comparar o ajuste de modelos de regressão não lineares, considerando os possíveis desvios de pressuposição sobre os resíduos, na descrição do crescimento dos frutos de cacaueiro do clone Sial-105. Os dados analisados foram extraídos de Brito e Silva (1983) e correspondem a um experimento realizado no Centro de Pesquisa de Cacau, em Ilhéus-BA. As variáveis estudadas foram o comprimento, diâmetro e volume do fruto tomados em função da sua idade. O uso da ponderação e incorporação da dependência residual foi eficiente pois tornou a modelagem mais coerente melhorando a qualidade do ajuste. Considerar a estrutura auto-regressiva de primeira ordem, quando necessária, leva a redução significativa do desvio padrão residual, tornando as estimativas mais confiáveis. O modelo Logístico foi o mais eficiente na descrição do crescimento do fruto do cacau.

Palavras-chave: Interpretação biológica. Medida biométrica. Modelo logístico. Theobroma cacao L..

\footnotetext{
*Corresponding author

${ }^{1}$ Received for publication in 06/03/2016; accepted in 06/29/2016.

Paper extracted from the master dissertation of the second author.

${ }^{2}$ Department of Statistics, Universidade Federal de Lavras, Lavras, MG, Brazil; joamuniz@dex.ufla.br, micherlania@bol.com.br, tales.jfernandes@des.ufla.br.
} 


\section{INTRODUCTION}

Cacao (Theobroma cacao L.) is a globally important fruit by being the raw material for chocolate production. This fruit is produced mainly in countries of West Africa, Latin America and Indonesia (FRANZEN; MULDER, 2007). The production of cacao beans in Brazil reached 255,200 tons in 2015, with its highest production in the States of Bahia (53.1\%), Para (41.5\%) and Rondonia (2.2\%), (IBGE, 2016).

Cacao fruits must be at the ideal maturation stage or near its physiological maturity stage for harvesting to avoid weight loss of dry beans. The harvesting of unripe fruits, in general, results in weight loss of up to $20 \%$, compared to the harvesting of ripe fruits, and fruits with reduced sugar content, affecting the fermentation process and, consequently, the final product quality (MARTINS et al., 2011). According Cavalini et al. (2006), the fruit maturation stage at harvesting is a major factor of loss at post-harvest, however, it is usually subjectively assessed through the fruit external color and size, and there is no consensus for their standardization between producers.

The results of evaluations on growth processes and plant and fruit development are essential for the proper management of cacao crops, assisting in establish correct application of treatments, such as fertilizer and irrigation, plan the planting season and, especially, the harvest season (SANTOS et al., 2009). Several studies have used nonlinear regression models to describe fruit growth, which summarized the data in a few parameters, enabling practical interpretations (BALAGUERA-LÓPEZ et al., 2012; MARO et al., 2012; PRADO et al., 2013; FERNANDES et al., 2014). Almeida and Valle (1995) evaluated the fruit and seed growth of seven cacao genotypes by fit Logistic functions and polynomial regression to the descriptions of total dry matter accumulation of fruits and seeds and found different parameter estimates for the genotypes evaluated.

Regression analysis fit for nonlinear models must consider the following assumptions for inferences on the parameters: the residues must be independent, have the same variance and have normal distribution. The estimates may be biased and estimation of errors may be overestimated or underestimated when these assumptions are not considered (MAZZINI et al., 2005; SAVIAN; MUNIZ, 2007; MENDES et al., 2008; CARNEIRO, et al., 2014).

When dependent residues are present, Morettin and Toloi (2004) suggest to incorporate the residual autocorrelation in the modeling, and when the variances are not homogeneous, Pasternak and Shalev (1994) suggest to perform inverse-variance weighting. When the residue does not follow the normal distribution, in general, researchers transform the data to lead to a normality, make inferences based on the distribution of errors (GUEDES et al., 2014) or use the theory of generalized linear models (KOKONENDJ;; DEMÉTRIO; ZOCHI, 2007). Fernandes et al. (2014) evaluated the coffee fruit growth, comparing the fit of Logistic and Gompertz models, both weighted, and found the best fit for the Gompertz model. Mazzini et al. (2005) performed inverse-variance weighting, and also used residual autocorrelation in the fit of the Brody, Gompertz, Logistic and von Bertalanffy models to growth data of Hereford and Nellore calves and found estimates for the parameters with a lower standard error.

Nonlinear models have been used in plant science studies with satisfactory results, which allowed to estimate fruit growth parameters with biological interpretation, for example, on dwarf date palm (TERRA; SAVIAN; MUNIZ, 2010), dwarf green coconut (PRADO; SAVIAN; MUNIZ, 2013), the Cerrado pequi (FERNANDES et al., 2015) and cashew (MUIANGA et al., 2016). These models were also used in the description of the germination curve of seeds (SOUSA et al., 2014), plant growth (PEREIRA et al., 2014) and canopy diameter (WYZYKOWSKI et al., 2015) of coffee plants.

The objective of this work was to compare the fit of nonlinear regression models, considering residual analysis and assumption violations, in the description of the cacao (clone Sial-105) fruit growth.

\section{MATERIAL AND METHODS}

The data used to illustrate the fit of the models were taken from an experiment conducted by Brito e Silva (1983), in which they measured the fruit length $(\mathrm{cm})$, diameter $(\mathrm{cm})$ and volume $\left(\mathrm{cm}^{3}\right)$ of shaded cacao (Theobroma cacao L.) plants (clone Sial-105). The first measuring was performed 31 days after pollination and the others each 15 days until reaching 180 days, totaling eleven observations.

The sample variance was estimated at each colleting and the Hartley's maximum F test at 5\% of significance level was applied to verify their homogeneity. When the results were significant, the parameter estimates were found by inverse-variance weighting, as suggested by Pasternak and Shalev (1994).

Nonlinear Logistic (1) and Gompertz (2) models were used to estimate the growth curve parameters (length, diameter and volume) of cacao fruits based on the equations:

$$
\begin{gathered}
Y_{i}=\frac{A}{1+e^{k\left(B-t_{i}\right)}}+u_{i} \\
Y_{i}=A e^{\left(-e^{k\left(B-t_{i}\right)}\right)}+u_{i}
\end{gathered}
$$

where $\mathrm{Y}_{i}$ is the average value (length, diameter or volume) in the time $t$ (days); $A$ is the 
asymptotic value for the fruit, i.e., the expected value for the fruit measure at ripening; $k$ is the growth rate for this measure; $B$ is the age at which the characteristic reaches the inflection point, where the fruit growth decelerate to a stabilized growth at its maximum value of $A ; \mathrm{t}_{i}$ is the time at the $\mathrm{i}$-th measurement (days after pollination); $u_{i}=\rho_{1} u_{i-1}+\cdots+\rho_{p} u_{i-p}+\varepsilon_{i}, \quad$ with $i=2, \ldots, n ; n$ as the number of times in which growth measures were performed; $u_{i}$ is the residue of the fit in the i-th time; $\rho_{1}$ is the first-order autoregressive parameter; $u_{i-1}$ is the residue of the fit in the time immediately previous to the i-th measurement; $\rho_{p}$ is the p-order autoregressive parameter; $u_{i-p}$ is the residue of the fit in the $p$ times previous to the $\mathrm{i}$-th measurement; $\varepsilon_{i}$ is the white noise with normal distribution $N\left(0, \sigma^{2}\right)$. In the case of independent errors, then $u_{i}=\varepsilon_{i}$ (MAZZINI et al., 2005).

According to Tsoularis and Walace (2002), the Logistic model presents maximum growth rate at the inflection point $\left(t_{i}=B\right)$, in this case $\mathrm{Y}_{i}=\frac{A}{2}$ i.e., the rate is maximum at the time in which the fruit reaches half of its development, from which the growth rate decreases until stabilizes and the measures to reach the asymptotic value of $A$. This results make the Logistic model to be symmetrical in relation to the inflection point. The inflection point in the Gompertz model is also reached when $t_{i}=B$ however, in this point $Y_{i}=\frac{A}{e}$ indicating that the fruit reaches the maximum growth rate before reaching half of its asymptotic value to maturity.

The estimation of parameters of nonlinear models was performed by minimizing the sum of squared errors from the nonlinear normal equations system, which has no explicit solution, requiring the use of iterative processes (SOUZA, 2007), for which the Gauss-Newton was adopted (MUNIZ; SAVIAN; SCALON, 2008; SOUZA et al., 2010; ZEVIANI et al., 2012; AMANCIO et al., 2014; CARNEIRO et al., 2014).

The $\mathrm{R}$ software (R DEVELOPMENT CORE TEAM, 2014) was used for the fit of the models, estimating the parameters by the gnls, a function that uses least square methods (ordinary, weighted and generalized) and the iterative algorithm of Gauss-Newton of the nlme package (PINHEIRO et al., 2013).

The Shapiro-Wilk test was performed to verify the normality of errors and the Breuch-Pagan test to evaluate the homogeneity of variance of residues. The verification of presence of residual autocorrelation was performed as follows: the fit of the models considered the independent errors; the vector of residues was estimated by the Durbin-Watson test (DW), verifying the existence of first-order autoregressive parameters (AR1); and when the DW test was significant, the fit was performed again, considering such residual dependence.

The agronomic interpretation of parameters and the fit quality was considered for the selection of the most appropriate model, based on the following criteria:

i. Residual standard deviation (RSD), expressed by: $R S D=\sqrt{R M S}$, where RMS is the residual mean square;

ii. Adjusted coefficient of determination

$\left(R_{a j}^{2}\right)$, expressed by $R_{a j}^{2}=1-\left[\frac{(n-1)\left(1-R^{2}\right)}{(n-q)}\right]$, where $R^{2}$ is the non-fitted coefficient of determination, $n$ is the number of the times and $q$ is the number of parameters of the model; iii. Akaike's information criterion corrected (AICc) obtained by:

$$
A I C_{c}=n \ln \left(\frac{R S S}{n}\right)+2(q+1)+\frac{2(q+1)(q+2)}{n-(q+2)}
$$

where RSS is the residual squared sum.

According to these criteria, a model must be preferred when it presents lower values of RSD and AICc, and adjusted coefficient of determination $\left(R_{a j}^{2}\right)$ closer to 1 .

\section{RESULTS AND DISCUSSION}

According to the results found for the Shapiro-Wilk (SW), Breusch-Pagan (BP) and Durbin-Watson (DW) tests, the assumptions of normality and homogeneity of variance of the vector of errors were met for the length, diameter and volume of cacao (Theobroma cacao L.) fruits in the three models ( $p$-value $>0.05$; Table 1$)$. The results of the DW test showed that the Gompertz model for the length variable, and both models for the diameter variable, had presence of residual autocorrelation (p-value $<0.05)$, suggesting the possibility of incorporating the first-order autoregressive parameter (AR1) in the fit of the models (Table 1). Similarly Prado et al. (2013) and Sousa et al. (2014) found autocorrelation of residues using Logistic and Gompertz models to describe the dwarf coconut fruit growth and coffee seed germination, respectively. 
Table 1. P-values in the Shapiro-Wilk (SW), Breusch- Pagan (BP) and Durbin-Watson (DW) tests, used for analysis of residues estimated after the fit of Logistic and Gompertz models to the measurements of length, diameter and volume of the cacao (Theobroma cacao L.) fruits.

\begin{tabular}{lll}
\hline Length & Logistic & Gompertz \\
\hline SW & 0.5652 & 0.9916 \\
BP & 0.2863 & 0.4149 \\
DW & 0.0785 & $0.0064^{*}$ \\
\hline Diameter & Logistic & Gompertz \\
\hline SW & 0.1842 & 0.1528 \\
BP & 0.5356 & 0.8093 \\
DW & $0.0061^{*}$ & $0.0045^{*}$ \\
\hline Volume & Logistic & Gompertz \\
\hline SW & 0.1334 & 0.3848 \\
BP & 0.1207 & 0.1283 \\
DW & 0.3247 & 0.1782 \\
\hline
\end{tabular}

*significant test at 5\%.

The Hartley's maximum $\mathrm{F}$ test indicated that the sample variances were heterogeneous for the length $(\mathrm{Fc}=12.34)$, diameter $(\mathrm{Fc}=23.43)$ and volume $(\mathrm{Fc}=74.98)$, therefore, the inverse-variance weighting in the process of the estimation of the parameters was needed, as suggested by Pasternak and Shalev (1994).

Only the Gompertz model indicated the need for the (AR1) for the length, and all parameters were significant by the t-test at $5 \%$ of significance.

Table 2. Estimates and their respective standard errors and fit quality criteria for the parameters of the Logistic and Gompertz models, found by the ordinary least square method (OLSM) and generalized least square method (GLSM, by inverse-variance weighting and considering first-order autoregressive errors), for the description of the length of cacao (Theobroma cacao L.) fruits.

\begin{tabular}{lllll}
\hline Estimates/ & \multicolumn{1}{c}{ OLSM } & \multicolumn{2}{c}{ GLSM } \\
Evaluators & Logistic & Gompertz & Logistic & Gompertz \\
\hline $\mathrm{A}$ & $10.8642(0.2740)$ & $11.2043(0.4798)$ & $10.8157(0.2166)$ & $11.0487(0.4252)$ \\
$\mathrm{B}$ & $67.7198(2.4084)$ & $54.9610(3.0343)$ & $68.4819(2.1161)$ & $56.7336(3.7943)$ \\
$k$ & $0.0472(0.0050)$ & $0.0310(0.0048)$ & $0.0515(0.0057)$ & $0.0353(0.0062)$ \\
$\rho_{1}$ & -- & -- & - & $0.2649(0.0430)$ \\
$\mathrm{R}_{\mathrm{aj}}^{2}$ & 0.9826 & 0.9692 & 0.9828 & 0.9705 \\
$\mathrm{RSD}$ & 0.4628 & 0.6145 & 0.3004 & 0.3931 \\
$\mathrm{AICc}$ & 22.0592 & 28.4307 & 21.0791 & 28.2643 \\
\hline
\end{tabular}

The incorporation of the first-order autoregressive parameter improved the fit quality of the models, with a reduction of about $40 \%$ in the residual standard deviation for the Gompertz and $35 \%$ for the Logistic model. A slight improvement in $\mathrm{R}_{\mathrm{aj}}^{2}$

and Akaike's information criterion corrected (AICc) was found, and the Logistic model showed the best results (Table 2). Therefore, the Logistic model was the most appropriate to describe the length of cacao fruits. Result that was similar to those found by Terra, Savian and Muniz (2010), who described the length of dwarf date palm fruits. According to the characteristics established by Tsoularis and Walace (2002) and based on estimates of the parameters $A$ and $B$ of the Logistic model, the cacao fruits reached a length of $5.41 \mathrm{~cm}$ at approximately 68 days, which represents half of the total development $(A)$.

The cacao fruit diameter presented a reduction in the estimates of the parameter $A$ when the fit considered the weighting and the presence of (AR1), both in the Gompertz $(8.9531 \mathrm{~cm})$ and Logistic $(8.6934 \mathrm{~cm})$ models (Table 3$)$, which were closer to the maximum value reached by the cacao fruits in the experiment $(8.30 \mathrm{~cm})$. The estimates of the parameter $B$ of the Logistic model indicated that the maximum growth rate must be found around 92 days of age, when the fruit reaches $4.35 \mathrm{~cm}$ in diameter. These results are within the ranges of age (between 90 and 105 days) in which Almeida and Valle (1995) found the maximum rate of total dry weight accumulation in cacao fruits. 
Table 3. Estimates and their respective standard errors and fit quality criteria for the parameters of the Logistic and Gompertz models, found by the ordinary least square method (OLSM) and generalized least square method (GLSM, by inverse-variance weighting and considering first-order autoregressive errors), for the description of the diameter of cacao (Theobroma cacao L.) fruits.

\begin{tabular}{lccrr}
\hline Estimates/ & OLSM & \multicolumn{2}{c}{ GLSM } \\
Evaluators & \multicolumn{1}{c}{ Logistic } & Gompertz & \multicolumn{1}{c}{ Logistic } & \multicolumn{1}{c}{ Gompertz } \\
\hline $\mathrm{A}$ & $8.8514(0.2729)$ & $9.5059(0.6820)$ & $8.6934(0.2794)$ & $8.9531(0.6258)$ \\
$\mathrm{B}$ & $90.4553(2.5944)$ & $78.5907(4.3654)$ & $91.6088(1.8625)$ & $83.6243(2.9678)$ \\
$k$ & $0.0468(0.0046)$ & $0.0271(0.0049)$ & $0.0541(0.0058)$ & $0.0373(0.0070)$ \\
$\rho_{1}$ & -- & -- & $0.2894(0.0527)$ & $0.5932(0.1198)$ \\
$\mathrm{R}_{\mathrm{aj}}^{2}$ & 0.9885 & 0.9739 & 0.9859 & 0.9652 \\
$\mathrm{RSD}$ & 0.3534 & 0.5437 & 0.1146 & 0.1901 \\
$\mathrm{AICc}$ & 16.2597 & 25.7350 & 17.3259 & 24.9965 \\
\hline
\end{tabular}

A significant reduction in the residual standard deviation (RSD) of the Logistic (68\%) and Gompertz (65\%) models was also found (Table 3), when the weighting and first-order autoregressive parameters was incorporated, making the estimates most reliable. The model that best fitted these data was the Logistic, which had the lowest values of RSD and AICc, and presented the greatest $R_{a j}^{2}$, confirming the results found by Prado et al. (2013), who also indicated the Logistic model for the description of longitudinal and transversal diameter of dwarf coconut fruits.

The estimates of the evaluators of fit quality were relatively similar, with high values for the fitted coefficient of determination, with slight advantage in favor of the Logistic model, which had the lowest values of RSD and AICc, indicating that this model was also more appropriate to describe the volume growth of cacao fruits.

Table 4. Estimates and their respective standard errors and fit quality criteria for the parameters of the Logistic and Gompertz models, found by the ordinary least square method (OLSM) and generalized least square method (GLSM, by inverse-variance weighting and considering first-order autoregressive errors), for the description of the volume of cacao (Theobroma cacao L.) fruits.

\begin{tabular}{|c|c|c|c|c|}
\hline \multirow{2}{*}{$\begin{array}{l}\text { Estimates/ } \\
\text { Evaluators }\end{array}$} & \multicolumn{2}{|c|}{ OLSM } & \multicolumn{2}{|c|}{ GLSM } \\
\hline & Logistic & Gompertz & Logistic & Gompertz \\
\hline $\bar{A}$ & $403.8909(12.1681)$ & $409.2894(16.4420)$ & $410.3252(13.3742)$ & $414.3086(17.3048)$ \\
\hline B & $106.9998(1.8218)$ & $100.0315(1.9836)$ & $108.6868(2.1989)$ & $102.0661(2.8083)$ \\
\hline$k$ & $0.0930(0.0133)$ & $0.0643(0.0116)$ & $0.0931(0.0185)$ & $0.0679(0.0153)$ \\
\hline$\rho_{1}$ & --- & --- & --- & --- \\
\hline $\mathrm{R}_{\mathrm{aj}}^{2}$ & 0.9879 & 0.9845 & 0.9873 & 0.9837 \\
\hline RSD & 20.1128 & 23.4217 & 22.1078 & 25.7219 \\
\hline $\mathrm{AICc}$ & 105.1694 & 108.5214 & 136.9541 & 139.6009 \\
\hline
\end{tabular}

The use of weighting and incorporation of the autocorrelation parameter $\left(\rho_{1}\right)$ in the fit, when needed, for the three growth variables evaluated showed that, in general, it reduced the standard error of the estimates of the parameters, and make the biological interpretation of the parameter $A$ closer to the actual values found in the experiment. It also improved the evaluators of fit quality, with significant reduction in RSD, confirming the results of Mazzini et al. (2005), Prado et al. (2013) and Sousa et al. (2014), who found more accurate estimates of parameters of growth when considered the first-order autoregressive structure (AR1) of the residues in the growth curve of Hereford cattle, dwarf coconut and coffee seed germination, respectively.

Based on the results of the fit quality criteria (Tables 2, 3 and 4), the Logistic model was the most appropriate to describe the cacao fruit growth in length, diameter and volume. This result confirms those found by several authors in the literature, who reported the Logistic model as the most appropriate to describe the growth curve of fruits, such as Maro et al. (2012), who indicated this model to describe the growth in length and diameter of raspberry fruit, Terra, Savian and Muniz (2010), who evaluated the length and diameter of dwarf date palm fruits, and Balaguera-López et al. (2012), who described the growth of gabiroba fruits by analyzing their fresh weight as a function of their age.

The length $(\mathrm{cm})$ of the fruits were underestimated by the two models in their early ages (Figure 1a). Fruits length, in general, progresses rapidly until 105 days and then slower up to 150 days of age. Both models also underestimate the diameter $(\mathrm{cm})$ in the early ages of the fruits (Figure 1b), which had a marked increase until 150 days and a reduced growth rate from this age. The volume presented good fit of the models in the early ages of the fruits (Figure 1c), which slowly increased up to 90 days, accelerating from this age up to 150 days and reducing from this age. 


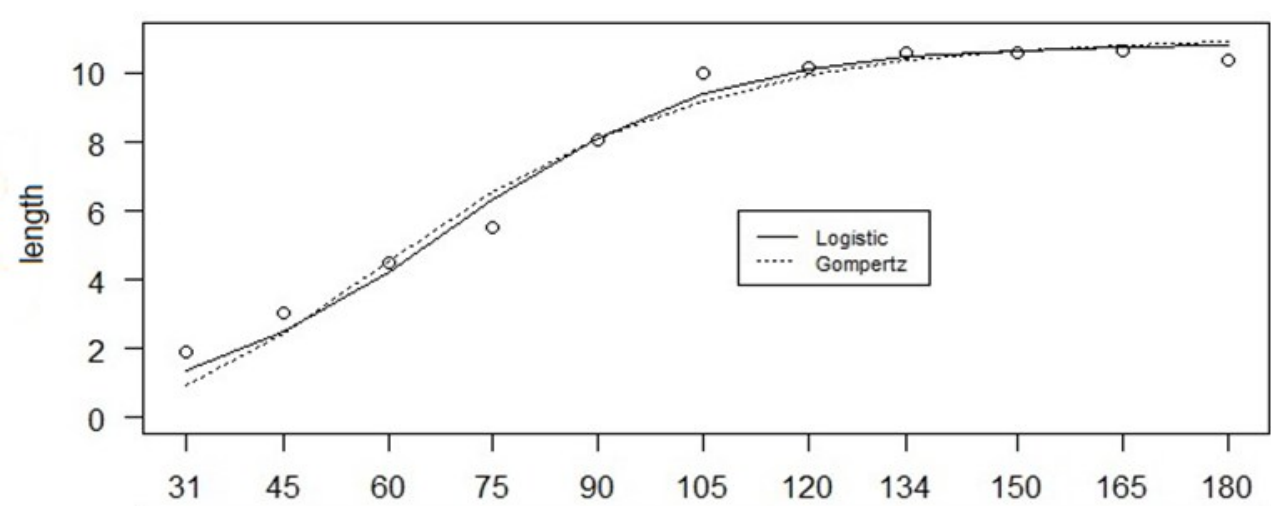

(a)

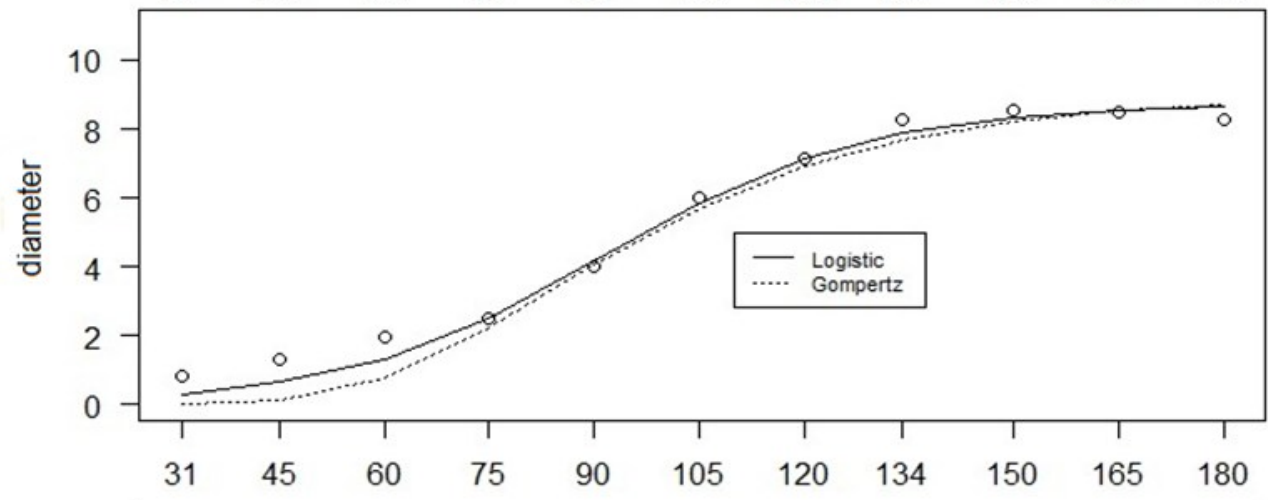

(b)

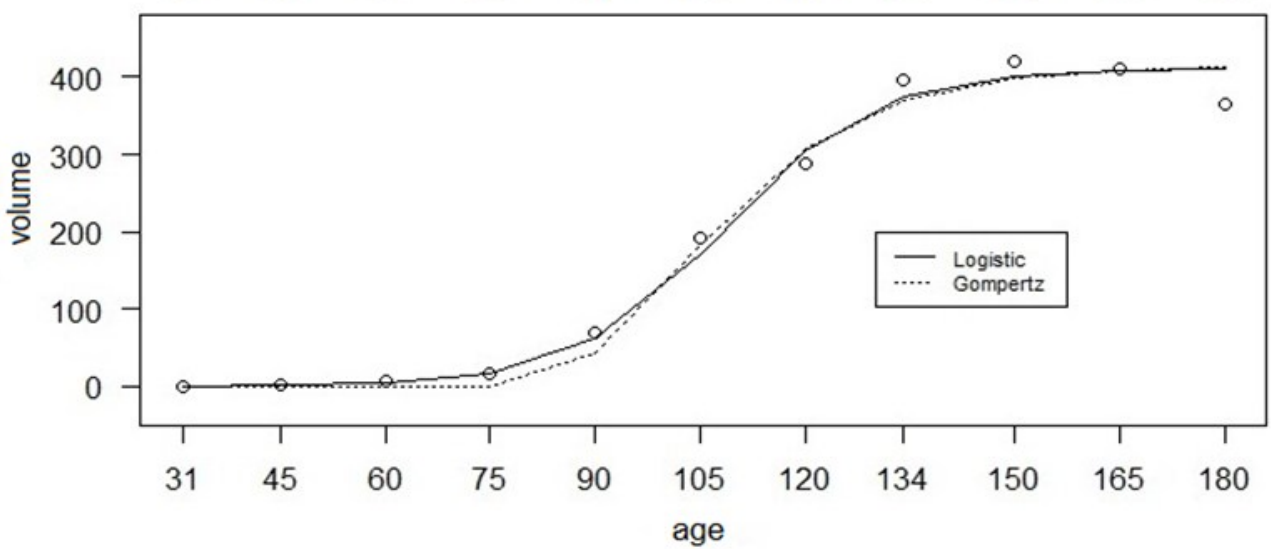

(c)

Figure 1. Fit of the weighted Logistics and Gompertz models to the length (a), diameter (b) and volume (c) data of cacao (Theobroma cacao L.) fruits, considering first-order autoregressive processes (AR1) when needed.

The measures of the fruit over time (Figure 1) confirm the results of Carvalho et al. (2009), who reported that the cacao fruit development is characterized by an early exponential growth, then a linear phase, stabilizing at the maturation stage and a size reduction at the end of its maturation stage (ripening) due to water loss. Thus, despite the data being old, the results agreed with current studies on the cacao fruit growth by the biological interpretation of parameters and growth pattern found.

The incorporation of the first-order autoregressive parameter in the models with residual dependence reduced considerably the RSD values in both models (Tables 2 and 3), which was also observed by Prado, Savian and Muniz (2013). The weighting did not improve the fit quality when the residual dependency was not found (Table 4).

\section{CONCLUSION}

The incorporation of inverse-variance weighting and the first-order autoregressive structure (AR1) of the residues was efficient, providing consistent estimates of parameters, improving the fit quality. Considering the first-order autoregressive structure, when needed, leads to a significant reduction in the residual standard deviation, making the estimates more reliable. The Logistic model was the most appropriate to describe the growth curve of cacao (Theobroma cacao L.) fruits.

\section{REFERENCES}

ALMEIDA, A. A. F.; VALLE, R.R. Análise de crescimento do fruto $\mathrm{e}$ das sementes de sete 
genótipos de Theobromacacao L. Pesquisa Agropecuária Brasileira, Brasília, v. 30, n. 7, p. 909-916, 1995.

AMANCIO, A. L. L. et al. Use of mathematical models in the study of bodily growth in GIIF strain Nile tilápia. Revista Ciência Agronômica, Fortaleza. v. 45, n. 2, p. 257-266, 2014.

BALAGUERA-LÓPEZ, H. E. et al. Growth of champa fruit under agroecological conditions of Miraflores, Boyacá, Colombia. Pesquisa Agropecuária Brasileira, Brasília, v. 47, n. 12, p. 1722-1730, 2012.

BRITO, I. C.; SILVA, C. P. Medidas biométricas do fruto do cacaueiro durante seu desenvolvimento. Sitientibus, Feira de Santana, v. 2, n. 3, p. 59-66, 1983.

CARNEIRO, A. P. S. et al. Identidade de modelos não lineares para comparar curvas de crescimento de bovinos da raça Tabapuã. Pesquisa Agropecuária Brasileira, Brasília, v. 49, n. 1, p. 57-62, 2014.

CARVAlhO, C. A. L. Tópicos em Ciências Agrárias. Cruz das Almas, BA. 2009. 296 p.

CAVALINI, F. C. et al. Maturity indexes for 'Kumagai' and 'Paluma' guavas. Revista Brasileira de Fruticultura, Jaboticabal, v. 28, n. 2, p. 176-179, 2006.

FERNANDES, T. J. et al. Parametrization effects in nonlinear models to describe growth curves. Acta Scientiarum Technology. Maringá, v. 37, n. 4, p. 347-402, 2015.

FERNANDES, T. J. et al. Seleção de modelos não lineares para descrição das curvas de crescimento do fruto do cafeeiro. Coffee Science, Lavras, v. 9, n. 2, p. 207-215, 2014.

FRANZEN, M.; MULDER, M. B. Ecological, economic and social perspectives on cocoa production worldwide. Biodiversity and Conservation, Bengaluru, v. 16, n. 13, p. $3835-$ 3849, 2007.

GUEDES, T.A. et al. Applying regression models with skew-normal erros to the height of bedding plants of Stevia rebandiana (Bert) Bertoni. Acta Scientiarum Technology. Maringá, v. 36, n. 3, p. 463-468, 2014.

INSTITUTO BRASILEIRO DE GEOGRAFIA E ESTATÍSTICA. Estatística da Produção Agrícola. Rio de Janeiro, RJ. 2016. 74 p.
KOKONENDJI, C.; DEMÉTRIO, C. G. B.; ZOCHI, $\mathrm{S}$. S. On Hinde-Demétrio regression models for overdispersed count data. Statistical Methodology, Nova Deli, v. 4, p. 277-291, 2007.

MARO, L. A. C. et al. Ciclo de produção de cultivares de framboeseiras (Rubusidaeus) submetidas a poda drástica nas condições do sul de Minas Gerais. Revista Brasileira de Fruticultura, Jaboticabal, v. 34, n. 2, p. 435-441, 2012.

MARTINS, J. M. et al. Melhoria da qualidade de cacau. Ilhéus, BA: CEPLAC/CENEX, 2011. 45 p.

MAZZINI, A. R. de A. et al. Curva de crescimento de novilhos Heroford: heterocedasticidade e resíduos auto-regressivos. Ciência Rural, Santa Maria, v. 35, n. 2, p. 422-427, 2005.

MENDES, P. N. et al. Modelo Logístico difásico no estudo do crescimento de fêmeas da raça Hereford. Ciência Rural, Santa Maria, v. 38, n. 7, p. $1984-$ 1990, 2008.

MORETTIN, P. A.; TOLOI, C. M. de C. Previsão de séries temporais. 3. ed. São Paulo, SP. 2004, 436p.

MUIANGA, C. A. et al. Descrição da curva de crescimento de frutos do cajueiro por modelos não lineares. Revista Brasileira de Fruticultura, Jaboticabal, v. 38, n. 1, p. 22-32, 2016.

MUNIZ, J. A.; SAVIAN, T. V.; SCALON, J. D. Parameters estimation in the model for in situ degradability of mertens and loften. Ciência e Agrotecnologia, Lavras, v. 32, n. 5, p. 1622-1628, 2008.

PASTERNAK, H.; SHALEV, B. A. The effect of a feature of regression disturbance on the efficiency of fitting growth curves. Growth, Development and Aging, Lakeland, v. 58, n. 1, p. 33-39, 1994.

PEREIRA, A. A. et al. Descrição do crescimento vegetativo do cafeeiro cultivar Rubi MG 1192, utilizando modelos de regressão, Coffee Science, Lavras, v. 9, n. 2, p. 236-271, 2014.

PINHEIRO, J. C. et al. NIme: linear andnonlinearmixedeffectsmodels. R PackageVersion 3.1-120. Disponível em: <http://cran.r-project.org/ web/packages/nlme/nlme.pdf $>$. Acesso em: $10 \mathrm{fev}$. 2015.

PRADO, T. K. L. et al. Ajuste do modelo Logístico na descrição do crescimento de frutos de coqueiros não verde por meio de algoritmos iterativos MCMC. 
Revista Brasileira de Biometria, São Paulo, v. 31, n. 2 , p. $216-232,2013$.

PRADO, T. K. L.; SAVIAN, T. V.; MUNIZ, J. A. Ajuste dos modelos Gompertz e Logístico aos dados de crescimento de frutos de coqueiro anão verde. Ciência Rural, Santa Maria, v. 43, n. 5, p. 803-809, maio 2013.

R DEVELOPMENT CORE TEAM R: a languageandenvironment for statisticalcomputing. Vienna: R Foundation for Statistical Computing, 2014. Disponível em: <http://www.R-project.org/>. Acesso em: 10 mar. 2014.

SANTOS, V. R. et al. Crescimento e produtividade agrícola de cana-de-açúcar em diferentes fontes de fósforo. Revista Brasileira de Engenharia Agrícola e Ambiental, Campina Grande, v. 13, n. 4, p. 389-396, 2009.

SAVIAN, T. V.; MUNIZ, J. A. A study of in situ degradability: heterogeneity of variances and correlated errors. Scientiae Agricola, Piracicaba, v. 64, n. 5, p. 548-554, 2007.

SOUZA, G. da S. Introdução aos modelos de regressão linear e não linear. 3. ed. Brasília, DF: Embrapa, 2007. 505 p.

SOUSA, I. F. et al. Fitting nonlinear autoregressive models to describe coffee seed germination. Ciência Rural, Santa Maria, v. 44, n. 11, p. 2016-2021, 2014.

SOUZA, L. A et al. Curvas de crescimento em bovinos da raça Indubrasil criados no Estado de Sergipe. Revista Ciência Agronômica, Fortaleza, v. 41, n. 4, p. 671-676, 2010.

TERRA, M. F.; MUNIZ, J. A.; SAVIAN, T. V. Ajuste dos modelos Logístico e Gompertz aos dados de crescimento de frutos da tamareira-anã (O'brien). Magistra, Cruz das Almas, v. 22, n. 1, p. 1-7, 2010.

TSOULARIS, A.; WALLACE, J. Analysis of logistic growth models. Mathematical Biosciences, Chicago, v. 179, n. 1, p. 21-55, 2002.

WYZYKOWSKI, J. et al. Análise do diâmetro de copa do cafeeiro recepado utilizando um modelo não linear misto. Revista Brasileira de Biometria, São Paulo, v. 33, n. 3, p. 243-256, 2015.

ZEVIANI, W. M. et al. Modelos não lineares para a liberação de potássio de estercos animais em latossolos. Ciência Rural, Santa Maria, v. 42, n. 10, p. 1789-1796, 2012. 